\title{
Basic Helix-Loop-Helix Domain-Containing Protein USF3
}

National Cancer Institute

\section{Source}

National Cancer Institute. Basic Helix-Loop-Helix Domain-Containing Protein USF3. NCI

Thesaurus. Code C134708.

Basic helix-loop-helix domain-containing protein USF3 (2245 aa, 242 kDa) is encoded by the human USF3 gene. This protein may play a role in the regulation of gene transcription. 